\title{
Pathogenic Race and Mating Type of Pyricularia oryzae from Soviet Union, China, Nepal, Thailand, Indonesia and Colombia
}

\author{
Hiroshi YaEgashi* and Masao Yamada**
}

\begin{abstract}
A total of 130 isolates of Pyricularia oryzae from 6 countries were tested for the identification of pathogenic race and mating type. The number of races identified from country of origin was, Soviet Union-3 Japanese races [3 international races], China-7 [9], Nepal-2 [2]. Thailand-3 [2], Indonesia-4 [4], and Colombia-5 [12]. The reaction of these races identified by means of Japanese and international rice cultivars did not always correspond. About $40 \%$ of the isolates used were of untetermined pathogenic race, because of inconsistent host reaction. The phenotypic variability in pathogenic reaction could be due to the heterogeneity of the differential rice cultivars as well as to the pathogenic change of the blast fungus itself. The presence of both mating types was confirmed in the isolates from China and Colombia, but in the Russian and Nepalese collection mating type A was only detected. On the other hand, all of the Indonesian isolates used were of mating type a.
\end{abstract}

(Received October 5, 1985)

Key words : Pyricularia oryzae, pathogenic race, mating type.

\section{Introduction}

Pyricularia oryzae Cav. causes blast, an economically important disease of rice (Oryza sativa L.) in all rice growing areas of the world. Pathogenic specialization in this causal agent was first reported by Sasaki in $1922^{15)}$, and several decades later a race differential system was developed in Japan, USA and other countries ${ }^{2,3,5,10,20)}$. In addition, to compare the pathogenicity of $P$. oryzae in different countries, an international set of differential cultivars was developed through the Japan-USA cooperative work ${ }^{1)}$, and two years later standardization of the international race numbers of $P$. oryzae was proposed by Ling and $\mathrm{Ou}^{12)}$. Since a set of differential rice cultivars was established in each country, numerous reports have been published on races of the rice blast fungus. These data have provided valuable information for genetic analysis of blast resistance and their use for developing resistant varieties, although there is controversy as to the frequency of pathogenic variation in this organism $4,9,11,13)$. However, information available on the blast resistance of various lines introduced from foreign countries is limited, because of lack of suitable test isolates pathogenic to given line. It appears that effective use

* National Institute of Agro-Environmental Sciences, Yatabe, Tsukuba, Ibaraki 305, Japan 農林 水産省農業環境技術研究所

** Hokuriku National Agricultural Experiment Station, Joetsu, Niigata 943-01, Japan 農林水産省 北陸農業試験場 
of resistance genes from foreign sources requires to know the ledge of pathogenicity of foreign isolates and their capacity for variation before blast-resistant varieties can be developed.

On the other hand, Hebert ${ }^{6)}$, Kato et al..$^{7}$, Ueyama et al. ${ }^{16)}$ and Yaegashi et al. ${ }^{17)}$ succeeded in combining compatible isolates under suitable condition for development of the perfect state of the blast fungus, which can serve as a good basis for genetic study of this organism. Since a survey of pathogenicity and cross fertility of blast isolates should provide basic information to select the isolates for genetic analysis of blast resistance, and to elucidate the mechanism of pathogenic variablility, an attempt was made to determine the pathogenic race and mating type of $P$. oryzae isolates collected in the Soviet Union, China, Nepal, Thailand, Indonesia and Colombia. Results are reported herein.

\section{Materials and Methods}

Monoconidial isolates obtained from blast specimens or cultures from the Soviet Union, China, Nepal, Thailand, Indonesia and Colombia were used for race identification and mating tests. Origins of the isolates used are indicated in Table 1. Seedlings of each set of Japanese and international differential rice cultivars were inoculated at the 4-leaf stage by spraying a spore suspension. Ten plants of each cultivar were inoculated with each isolate. Inoculated plants were incubated in a moist chamber at 26-28 $\mathrm{C}$ for 20 hours, then returned to the greenhouse. Seven to eight days after inoculation, the pathogenic race of each isolate was determined on the basis of reactions of the differential cultivars. The type of the most susceptible lesion produced on the leaves of the host was used as the criterion for estimating pathogenicity of the isolate. The test isolate was considered to be virulent if large whitish lesions (W or PW type) or large eyespots with brown margin (bG type) were induced on a given cultivar. On the other hand if no symptoms, brown pinpoint lesions (b type) or small eyespot lesions less than $1 \mathrm{~mm}$ in diameter with gray center (bg type) were incited, the isolate was considered to be avirulent to the cultivar. In case of seedling reaction differing from plant to plant, pathogenicity of the isolate was estimated from the lesion type of not less than 6 plants for convenience. Race identification was confirmed at least twice. In order to get information on pathogenic variability, an inoculation test of selected isolates was repeated 5 to 6 times during 1982 to 1984. Only results consistent through the repeated inoculation tests were shown, and others were shown as the undetermined pathogenic race even if the same result was obtainted in 5 times out of 6 trials.

Mating type classification was attemped for all isolates used. Mating type was determined by crossing monoconidial isolates with fertile tester lines of mating types A and a of isolates from finger millet [Eleusine coracana (L.) Gaertn.]. Grosses were made by pouring a mycelial suspension of the tester line over the surface of oat meal agar ( $50 \mathrm{~g}$ ground oat, $15 \mathrm{~g}$ agar in 1 liter of water) on which were placed mycelial plugs of unknown isolates. Petri dishes of crosses were incubated for $2-3$ weeks at $22 \mathrm{C}$ with continuous illumination. Other techniques for crossing were described previously ${ }^{18}$. 


\section{Results}

A total of 130 isolates of $P$. oryzae were tested for the identification of pathogenic

Table 1. Origin, race and mating type of the isolates of Pyricularia oryzae collected in Soviet Union, China, Nepal, Thailand, Indonesia and Colombia

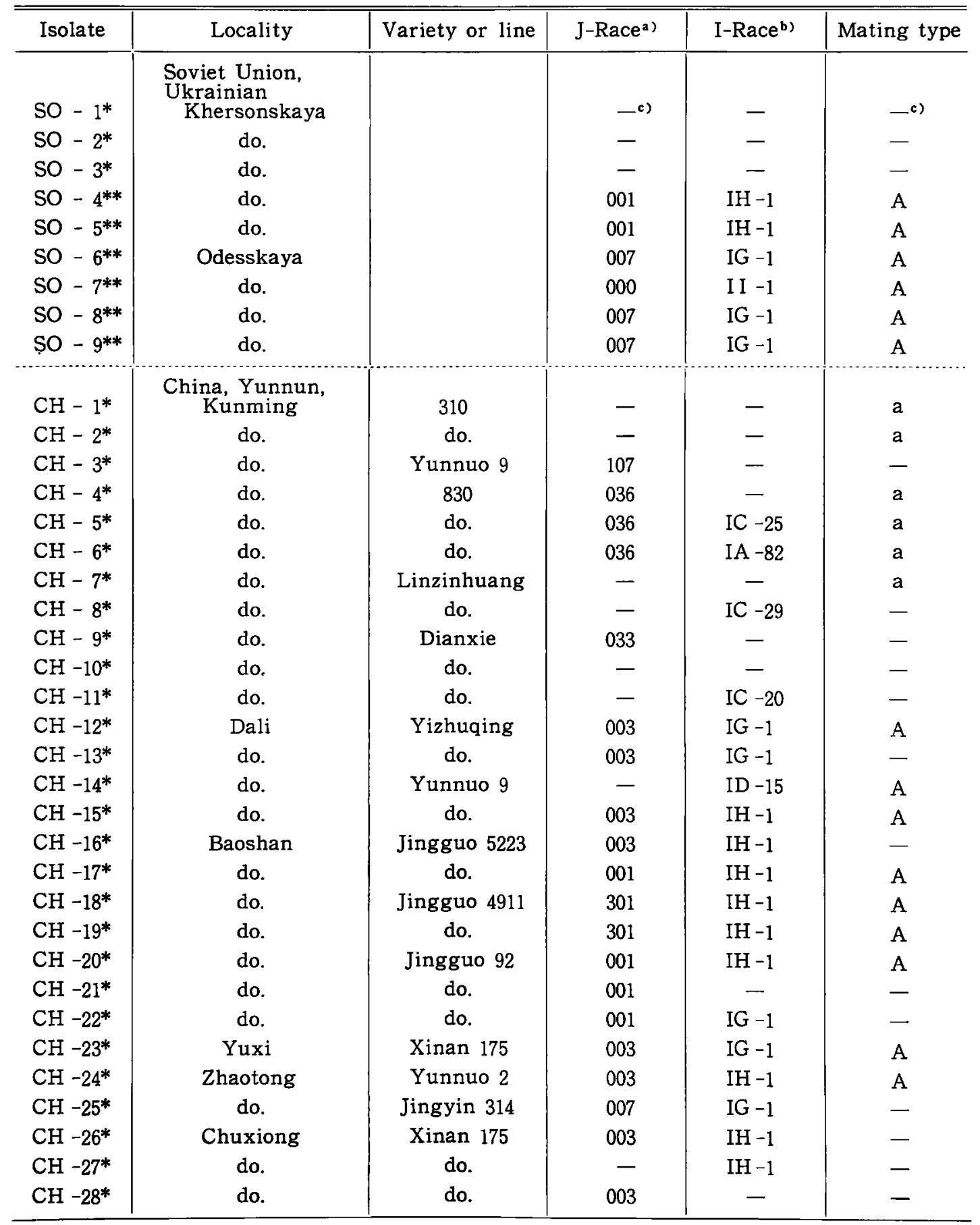


Table 1. continued

\begin{tabular}{|c|c|c|c|c|c|}
\hline Isolate & Locality & Variety or line & J-Race ${ }^{\text {a }}$ & I-Race $\left.{ }^{b}\right)$ & Mating type \\
\hline $\mathrm{CH}-29 *$ & Chuxiong & Xinan 175 & 003 & $\mathrm{IH}-1$ & - \\
\hline $\mathrm{CH}-30^{*}$ & do. & Jinnuo 1 & 003 & IH -1 & - \\
\hline $\mathrm{CH}-31^{*}$ & do. & do. & 003 & IG -1 & - \\
\hline $\mathrm{CH}-32^{*}$ & Ying jiang & Nanjiog 1 & - & ID -1 & - \\
\hline $\mathrm{CH}-33^{*}$ & do. & do. & - & ID -16 & - \\
\hline $\mathrm{CH}-34^{*}$ & do. & do. & - & - & - \\
\hline $\mathrm{CH}-35^{*}$ & do. & do. & - & ID -1 & - \\
\hline $\mathrm{CH}-36^{*}$ & Tengchong & Jingguo 332 & 003 & ID -15 & - \\
\hline $\mathrm{CH}-37^{*}$ & do. & Tengxian 1 & - & - & a \\
\hline $\mathrm{CH}-38^{*}$ & do. & do. & - & ID -1 & a \\
\hline $\mathrm{CH}-39^{*}$ & do. & Lufenggu & - & ID -1 & $\mathrm{a}$ \\
\hline $\mathrm{CH}-40^{*}$ & do. & do. & - & - & a \\
\hline $\mathrm{CH}-41^{*}$ & do. & do. & - & - & a \\
\hline$N E-1^{*}$ & $\begin{array}{l}\text { Nepal, Khumaltar, } \\
\text { Lalitpur }\end{array}$ & Taichung 176 & 007 & IG -1 & - \\
\hline $\mathrm{NE}-2^{*}$ & do. & do. & 007 & IG -1 & $\mathrm{~A}$ \\
\hline$N E-3^{*}$ & do. & do. & 007 & IG -1 & A \\
\hline $\mathrm{NE}-4^{*}$ & do. & Sankharika & 007 & IG -1 & A \\
\hline $\mathrm{NE}-\mathbf{5}$ & do. & do. & 002 & - & - \\
\hline $\mathrm{NE}-6$ & do. & do. & - & - & - \\
\hline $\mathrm{NE}-7$ & do. & do. & - & ID -13 & - \\
\hline $\mathrm{TH}-1$ & $\begin{array}{l}\text { Thailand, } \\
\text { Lod Bua Luang }\end{array}$ & RD 25 & - & IA -127 & - \\
\hline $\mathrm{TH}-2$ & do. & do. & 002 & - & - \\
\hline $\mathrm{TH}-3$ & do. & do. & 402 & IA -127 & - \\
\hline $\mathrm{TH}-4$ & do. & do. & 402 & IA -127 & - \\
\hline $\mathrm{TH}-5$ & do. & RD 23 & 106 & ID -13 & - \\
\hline IN $-1^{* *}$ & $\begin{array}{l}\text { Indonesia. } \\
\text { West Java, } \\
\text { Kumingan }\end{array}$ & S382b-18-2 & 006 & IG -1 & a \\
\hline IN $-2^{* *}$ & do. & do. & 006 & - & a \\
\hline IN $-3^{* *}$ & Bogor & Sigadis & - & IG -1 & a \\
\hline IN $-4^{* *}$ & do. & do. & 006 & ID -14 & a \\
\hline IN $-5^{* *}$ & do. & do. & 006 & IC -13 & a \\
\hline IN $-6^{* *}$ & do. & do. & - & - & a \\
\hline IN $-7^{* *}$ & do. & do. & 006 & - & a \\
\hline IN $-8^{* *}$ & do. & do. & - & $\mathrm{IG}-1$ & a \\
\hline IN $-9 * *$ & Garut & C 22 & - & - & a \\
\hline IN $-10^{* *}$ & do. & do. & - & - & a \\
\hline IN $-11^{* *}$ & do. & do. & 000 & IG -2 & a \\
\hline IN $-12^{* *}$ & do. & do. & - & $\mathrm{IG}-2$ & $\mathbf{a}$ \\
\hline IN $-13^{* *}$ & do. & do. & 000 & $\mathrm{IG}-2$ & a \\
\hline IN $-14^{* *}$ & do. & C 22 & 004 & - & a \\
\hline IN $-15^{* *}$ & do. & S263b-35-3-2 & 004 & - & a \\
\hline IN $-16^{* *}$ & do. & do. & 006 & - & a \\
\hline IN $-17^{* *}$ & do. & do. & 004 & - & a \\
\hline
\end{tabular}


Table 1. continued

\begin{tabular}{|c|c|c|c|c|c|}
\hline Isolate & Locality & Variety or line & J-Race $\left.{ }^{2}\right)$ & I-Race ${ }^{b)}$ & Mating type \\
\hline IN $-18^{* *}$ & Garut & $\mathrm{S} 263 \mathrm{~b}-35-3-2$ & 006 & - & a \\
\hline IN $-19^{* *}$ & do. & do. & - & IG -2 & a \\
\hline IN $-20^{* *}$ & do. & S382b-3-1 & - & - & a \\
\hline IN $-21^{* *}$ & do. & do. & - & - & a \\
\hline IN $-22^{* *}$ & do. & do. & - & - & a \\
\hline IN $-23^{* *}$ & do. & S263-37-2-2 & - & - & $\mathrm{a}$ \\
\hline IN $-24^{* *}$ & do. & do. & - & - & $\mathrm{a}$ \\
\hline IN $-25^{* * *}$ & do. & do. & 004 & - & a \\
\hline IN $-26^{* *}$ & do. & do. & 002 & - & a \\
\hline IN $-27^{* *}$ & $\begin{array}{l}\text { West Sumatra, } \\
\text { Gunun Medan }\end{array}$ & Bicol & - & - & a \\
\hline $\mathrm{CO}-1$ & $\begin{array}{l}\text { Colombia } \\
\text { villavicencio }\end{array}$ & IR 22 & - & IE -1 & - \\
\hline $\mathrm{CO}-2^{*}$ & do. & do. & 136 & - & - \\
\hline $\mathrm{CO}-3^{*}$ & do. & CICA 8 & - & IC -18 & - \\
\hline $\mathrm{CO}-4^{*}$ & do. & do. & - & - & - \\
\hline $\mathrm{CO}-5^{*}$ & do. & IRAT 128 & - & IG -1 & A \\
\hline $\mathrm{CO}-6^{*}$ & do. & do. & 002 & - & A \\
\hline $\mathrm{CO}-7^{*}$ & do. & 7639 & 一 & - & 一 \\
\hline $\mathrm{CO}-8^{*}$ & do. & do. & - & - & - \\
\hline $\mathrm{CO}-9^{*}$ & do. & 7955 & - & - & - \\
\hline $\mathrm{CO}-10^{*}$ & do. & do. & 132 & - & - \\
\hline $\mathrm{CO}-11^{*}$ & do. & IRAT 8 & 002 & $\mathrm{IH}-1$ & A \\
\hline $\mathrm{CO}-12^{*}$ & do. & do. & 002 & IC -24 & A \\
\hline $\mathrm{CO}-13^{*}$ & do. & do. & 002 & $\mathrm{IE}-4$ & $\mathrm{~A}$ \\
\hline $\mathrm{CO}-14^{*}$ & do. & do. & 002 & IC -23 & - \\
\hline $\mathrm{CO}-15^{*}$ & do. & Bbt 50 & - & - & - \\
\hline $\mathrm{CO}-16^{*}$ & do. & do. & - & ID -13 & - \\
\hline $\mathrm{CO}-17^{*}$ & do. & do. & - & IG -1 & - \\
\hline $\mathrm{CO}-18^{*}$ & do. & do. & 006 & IG -2 & - \\
\hline $\mathrm{CO}-19^{*}$ & do. & do. & 006 & - & a \\
\hline $\mathrm{CO}-20^{*}$ & do. & do. & 006 & - & - \\
\hline $\mathrm{CO}-21^{*}$ & do. & Tikal 2 & 002 & - & A \\
\hline $\mathrm{CO}-22^{*}$ & do. & do. & 一 & - & A \\
\hline $\mathrm{CO}-23^{*}$ & do. & Bg $90-2$ & 136 & IE -1 & - \\
\hline CO $-24^{*}$ & do. & CICA 7 & 002 & - & A \\
\hline $\mathrm{CO}-25^{*}$ & do. & do. & 002 & IH -1 & - \\
\hline $\mathrm{CO}-26^{*}$ & do. & Tetep & 136 & IC -8 & a \\
\hline $\mathrm{CO}-27^{*}$ & do. & do. & - & - & - \\
\hline $\mathrm{CO}-28^{*}$ & do. & MI-48 & - & - & - \\
\hline $\mathrm{CO}-29^{*}$ & do. & do. & 102 & - & - \\
\hline $\mathrm{CO}-30^{*}$ & Granada-Meta & 5869 & 136 & - & $\mathrm{a}$ \\
\hline CO $-31^{*}$ & do. & do. & 136 & - & - \\
\hline $\mathrm{CO}-32^{*}$ & do. & 5865 & - & - & - \\
\hline $\mathrm{CO}-33^{*}$ & do. & do. & - & IB -33 & - \\
\hline $\mathrm{CO}-34^{*}$ & do. & do. & - & - & - \\
\hline
\end{tabular}


Table 1. continued

\begin{tabular}{c|c|c|c|c|c}
\hline \hline Isolate & Locality & Variety or line & J-Racea) & I-Raceb) & Mating type \\
\hline CO $-35^{*}$ & Granada-Meta & 5865 & - & IC -1 & - \\
CO $-36^{*}$ & do. & do. & - & - & - \\
CO $-37^{*}$ & do. & do. & - & - & - \\
CO $-38^{*}$ & do. & IR 1529 & 006 & IG -1 & - \\
CO $-39^{*}$ & do. & do. & - & - & - \\
CO $-40^{*}$ & do. & do. & 006 & - & - \\
CO $-41^{*}$ & do. & do. & 006 & - & - \\
\hline
\end{tabular}

a). b): Races identified on Japanese and international differential cultivars, respectively.

c): Undetermined race or mating type.

d)*, **: Isolates collected in 1981 and 1982, respectively, and others collected in 1983.

race and mating type. Results are summarized with the source of isolates in Table 1 . Based on the reaction of the Japanese differential cultivars, 16 races were identified, and on the international set of differential rice cultivars, 23 races. The race identity of a fairly large number of isolates was not determined because of inconsistent host reaction. The number of races identified from country of origin was, Soviet Union-3 Japanese races [3 international races], China-7 [9], Nepal-2 [2], Thailand-3 [2], Indonesia-4 [4] and Colombia-5 [12]. Race composition varied with country of origin. In the isolates from the Soviet Union and Nepal, races 007 [IG-1] and 001 [IH-1] or 002 were identified. In addition, some characteristic isolates were obtained from the Russian collection. Three Russian isolates did not produce typical susceptible lesions on any differential cultivars despite a remarkable sporulation of these isolates on media but tiny grayish lesions (g type) were incited on Aichiasahi, Ishikarishiroke, Kanto 51, Tsuyuake and Yashiromochi. Moreover, the host reaction occasionally varied among replications. Results of a previous study ${ }^{19)}$ suggest that the Russian isolates may lack of the complementary gene(s) necessary for lesion expansion. Seven Japanese races and 9 international races were detected in the isolates from China, and race 003 was most prevalent. Thus, race composition of Chinese isolates was relatively complex, and the reaction of these races identified by means of Japanese and international differentials did not always correspond. For instance, race 003 corresponded to two international races IG-1 and IH-1. In contrast, IG-1 corresponded to Japanese races 001,003 and 301. Similar phenomena were observed in the isolates from Indonesia and Colombia. Another characteristic is that no isolates from Thailand, Indonesia or Colombia were virulent to Shin $2\left(P i-k^{s}\right)$, a Japanese differential cultivar susceptible to most Japanese isolates.

Of the 67 isolates for which a compatible mating type was determined, 26 isolates were type $A$ and 41 were type a. Mating type distribution by country of origin was, Soviet Union-6A, China-9A : 11a, Nepal-3A, Thailand-undetermined, Indonesia-27a, and Colombia-8A: 3a. Although mating types $A$ and a occurred with nearly equal frequencies among the isolates from China, both mating types were not detected in the same locality of Yunnan. All 27 of the Indonesian isolates were of mating type a. In isolates from the Soviet Union, Nepal and Colombia, however, the population sampled was not 
sufficiently large to determine mating type frequency, except for the presence of both mating types in Colombia. An attempt was made to produce the perfect state of $P$. oryzae by pairing isolates of determined mating types. No perithecia developed in any of the crosses attempted.

To determine the actual extent of pathogenic variability, additional surveys were conducted using some types of isolates inconsistent pathogenic reaction. Some isolates indicated a consistent reaction on differential cultivars, but with other isolates the pathogenic reaction varied among inoculation tests. The extent of pathogenic variation depended upon the isolates (Table 2); i.e., the pathogenic reaction of the one isolate (CH -34) varied from test to test for race identification, but in the others $(\mathrm{CH}-37$ and IN8) a different reaction was observed only once out of 6 replicates. The difference in pathogenic reaction of these isolates is, in most cases, caused by the pathogenic change to only a couple of differential cultivars. It would be too hasty a conclusion that the phenotypic difference in pathogenic reaction was caused by the pathogenic variation of the isolate itself. Since pathogenic race is determined on the basis of host reaction, a

Table 2. Inconsistent race reactions of some isolates of Pyricularia oryzae to Japanese differentials

\begin{tabular}{l|c|c|c|c|c|c}
\hline \hline \multirow{2}{*}{ Isolate } & \multicolumn{7}{|c}{ Replicate } \\
\cline { 2 - 7 } & I & II & III & IV & V & VI \\
\hline CH -34 & 016 & 136 & 137 & 537 & 102 & 136 \\
CH -37 & 136 & 136 & 106 & 136 & 136 & 136 \\
CH -41 & 116 & 136 & 136 & 136 & 106 & 106 \\
IN -6 & 006 & 006 & 002 & 006 & 004 & 006 \\
IN -8 & 006 & 006 & 006 & 006 & 006 & 004 \\
IN -27 & 002 & 002 & 002 & 002 & 102 & 102 \\
CO -9 & 132 & 132 & 132 & 132 & 136 & 136 \\
CO -17 & 002 & 007 & 006 & 006 & 006 & 006 \\
CO -37 & 132 & 136 & 132 & 136 & 136 & 132 \\
\hline
\end{tabular}

a) Race identification of replicates of I, II, and III was conducted in 1982, IV and V in 1983 , and VI in 1984.

b) *: Re-isolated culture from a lesion on the differential cultivar was used.

Table 3. Reaction of 36 selfed lines ${ }^{a)}$ of Sha-tiao-tsao-S to 4 isolates of Pyricularia oryzae

\begin{tabular}{l|r|r|r}
\hline \hline \multirow{2}{*}{ Isolate } & \multicolumn{3}{|c}{ Number of selfed lines to which ${ }^{\mathrm{b}}$} \\
\cline { 2 - 4 } & all S & $\mathrm{S} / \mathrm{R}$ & all R \\
\hline $\mathrm{CH}-41$ & 1 & 24 & 11 \\
$\mathrm{TH}-2$ & 0 & 0 & 36 \\
$\mathrm{CO}-17$ & 28 & 7 & 1 \\
$\mathrm{CO}-22$ & 7 & 28 & 1 \\
\hline
\end{tabular}

a) Each of selfed lines derived from a single seed of Sha-tiao-tsao-S selected randomly.

b) Five seedlings per line were used for inoculation test. All $S(R)$ : Selfed line consisted of susceptible (resistant) individuals only. S/R: Selfed line consisted of susceptible and resistant individuals. 
genetic homogeneity of the differential cultivars would be needed to know the true pathogenic variability. As a matter of fact, a heterogeneity of rice cultivar was occasionally observed in reaction to blast isolates. This tendency seems to be more remarkable in combination of rice cultivar and blast isolate orginating from different localities from each other. Reaction of Sha-tiao-tsao-S, the international differential cultivar, to 4 isolates was cited here as an example of the varietal heterogeneity. Five seedlings each of 36 selfed lines were sprayed with spore suspensions, and the reaction of each plant to the isolates was estimated 7 days after inoculation (Table 3). Reaction of the selfed lines of Sha-tiao-tsao-S differed from line to line; i.e., some lines consisted of susceptible or resistant seedlings only, and others were a mixture of susceptible and resistant seedlings. Moreover, the reaction of each selfed line varied with the isolates used.

\section{Discussion}

No perithecia developed in crosses of rice isolates, $P$. oryzae, despite the presence of both mating types. However, the possibility of pathogenic variation by hybridization can not eliminate completely, because the production of the perfect state of $P$. oryzae has been reported by Kato et $a .^{8)}$, although it seems to be rare. The frequency of mating type distribution was not always even. Especially in the Indonesian collection, mating type distribution was completely onesided. This is probably due to the difference in fitness to survive. Or, on the contrary, it may suggest the possibility of pathogenic variation not in terms of sexual recombination, because some races were identified from the Indonesian isolates consisting of the same mating type only.

Of most interest here is the question as to the pathogenic variability in $P$. oryzae. In fact, a little more than $40 \%$ of the isolates used were of undetermined pathogenic race, because of inconsistent host reaction. However, the phenotypic change in pathogenic reaction does not always mean the true pathogenic change of the isolate. This is because heterogeneity of the differential rice cultivar also gives rise to the phenotypic variation of pathogenicity. For instance, if a pair of heterogeneous rice cultivars is inclued among race differentials, a race can be divided into four races or to show inconsistent pathogenic reaction among replications. Since it is actually difficult to get seed stocks of rice in which the genetic background is completely identical, the phenomena mentioned above might be in a sence a natural result especially on the combination of rice cultivar and blast isolate without any long association. The importance of using isogenic lines is clearly evident for precise study of pathogenic variability.

Similar phenomena were observed also in the pathogenicity of blast isolates to differential rice cultivars. This means that the isolates belonging to a race are not always identical in spectrum of pathogenicity, as has been already pointed out by $\mathrm{Ou}^{14}$. There is a case that the isolates belonging to the same race are subdivided into two or more groups depending on the differential cultivars used. This result probably means that blast isolates are diverse in their genetic background. However, this is a distinctly different feature from the inconsistent reaction in pathogenicity. Races of the blast fun- 
gus were not transitory phenomena, but fairly fixed characters at least in more than half of the isolates used here. As far as pathogenic character is fixed, the isolates could be used for genetic study of blast resistance, although nothing could be better than using isolates with the same genetic background.

Grateful appreciation is expressed to Dr. T. T. Hebert, Professor Emeritus of North Carolina State University, for helpful advice in preparing the manuscript. We are indebted also to the following for providing rice seeds, fungus cultures or samples of diseased plant materials: Drs. E. D. Kovalenko (All Union Res. Inst. of Phytopathology, Soviet Union), Young-Hua, Wang (Yunnun Academy of Agric. Sci., China), K. K. Shrestha (Ministry of Agric., Nepal), B. H. Siwi (Sukamandi Res. Inst. for Food Crops, Indonesia), Sang-Won, Ahn (CIAT, Colombia), Eun Jong, Lee (Inst. Agric. Sci., Korea) and T. Morinaka (Nat. Inst. Agro-Env. Sci., Japan).

\section{Literature cited}

1. Atkins, J. G., Robert, A. L., Adair, C. R., Goto, K., Kozaka, T., Yanagida, K., Yamada, M. and Motsumoto, S. (1967). Phytopathology $57: 297-301$.

2. Bandong, J. M. and Ou, S. H. (1966). Philipp. Agric. 49:655-667.

3. Chiu, R. J., Chein, C. C. and Lin, S. Y. (1963). In The Rice Blast Disease. Proc. Symp. at IRRI. Johns Hopkins Press, Baltimore, pp. 245-255.

4. Giatgong, P. and Frederiksen, R. A. (1969). Phytopathology $59: 1152-1157$.

5. Goto, K., Yamanaka, S., Narita, T., Iwata, T., Ichikawa, H., Shimoyama, M., Kondo, M., Nakanishi, I., Imamura, S., Kumamoto, Y., Kono, M., Fujikawa, T., Okazaki, Z. and Tomiki, T. (1961). Special Res. Rep. on Disease and Insect Forecasting, Min. Agr. Forest. $5: 1-89$.

6. Hebert, T. T. (1971). Phytopathology $61: 83-87$.

7. Kato, H., Yamaguchi, T. and Nishihara, N. (1976). Ann. Phytopath. Soc. Japan $42: 507-510$.

8. Kato, H. and Yamaguchi, T. (1982). Ibid. $48: 607-612$.

9. Kozaka, T. (1979). In Proc. of the Rice Blast Workshop at IRRI, Los Banos, Phlippines, pp. 3-25.

10. Latterell, F. M., Tullis, E. C. and Collier, J. W. (1960). Plant Disease Reptr. 44:679-683.

11. Latterell, F.M. (1975). In Horizontal Resistance to the Blast Disease of Rice. Proc. Seminar at CIAT, Cali, Colombia, pp. 199-234.

12. Ling, K. C. and Ou, S. H. (1969). Phytopathology $59: 339-342$.

13. Ou, S. H. and Ayad, M. R. (1968). Ibid. $58: 179-182$.

14. Ou, S. H. (1984). Ann. Rev. Phytopathol. $22: 1-10$.

15. Sasaki, R. (1922). J. Plant Protection (Byogaichu Zasshi) $9:$ 631-645.

16. Ueyama, A. and Tsuda, M. (1975). Trans. Mycol. Soc. Japan 16:420-422.

17. Yaegashi, H. and Nishihara, N. (1976). Ann. Phytopath. Soc. Japan $42: 511-515$.

18. Yaegashi, H. (1981). Bull. Tohoku Natl. Agric. Exp. Stn. $63: 49-125$.

19. Yaegashi, H. and Yamada, M. (1984). Ann. Phytopath. Soc. Japan $50: 664-667$.

20. Yamada, M., Kiyosawa, S., Yamaguchi, T., Hirano, T., Kobayashi, T., Kushibuchi, K. and Watanabe, S. (1976). Ibid. $42: 216-219$.

和 文 摘 要

八重樫博志・山田昌雄：ソ連，中国，ネパール，タイ、インドネシアおよびコロンビア産イネいむち病菌の レースと交配型

6 カ国産イネいもち病菌計 130 菌株についてレースと交配型の検定を行った。日本のレース判別品種（およ び国際レース判別品種) により同定したレースの数は, ソ連産菌株で 3 種類 ( 3 種類), 中国産菌株で 7 種類 ( 9 種類), ネパール産菌株で 2 種類 ( 2 種類), タイ産菌株で 3 種類 ( 2 種類), インドネシア産菌株で 4 種類 ( 4 種類)，およびコロンビア産菌株で 5 種類 (12種類) であった。日本のレース判別品種と国際レース判別品 種とで検定した結果は必ずしも一致しなかった。また，供試菌株の約40\%は，一部の品種における反応が反復 実験の度に異なったため,レースを同定できなかった。レース反応が一定しない理由としては, 菌自体の病原 
性変異のほか, 一部の判別品種の遭伝的不均一性が関与していると考えられる。中国およびコロンビア産菌桥 では雨交配型の存在が確認されたが, ソ連およびネパール産菌株では交配型Aだけが確認された。なお、イン ドネシア産菌怢の交配型は, 全供菌株試とも交配型 $\mathrm{a}$ であった。 